\title{
Institutional Capacities in the Land Development for Housing on Greenfield Sites in Istanbul
}

\author{
Sevkiye Sence TURK, Willem K. KORTHALS ALTES \\ Published in Habitat International 34 (2010) 183-195
}

\section{Abstract}

Accommodating urban growth in the fast growing city of Istanbul encounters several problems. This paper discusses the development of greenfield sites in Istanbul by examining the institutional structure of the land development process of some recent large-scale housing projects using a framework of institutional analysis. The result reveals that the public (through both the central government and the local municipalities) has an important role in land development by acting as both regulator and investor. These roles have been empowered by the recent changes in the law. Success has been achieved in terms of the quality and quantity of housing built on greenfield sites in Istanbul over the last decade. However, the price of serviced urban plots in the legal land market remains high, and it remains difficult for the lowand mid-income groups to gain entry to the property market.

\section{Introduction}

Urbanization of large cities in the developing world is proceeding strongly. Often the planning system cannot accommodate this growth and a large part of this urbanization occurs in informal settlements. Much planning effort has recently gone into regularizing (formalizing) these settlements, which may result in a more secure tenure (Zevenbergen, 2004), which may become the basis on which the inhabitants can develop wealth. However, these informal settlements are often located in physically challenging locations and are exposed to risks. It may therefore be appropriate to enhance the planning process so that it can cater to the large population growth by providing ample serviced plots. This demands another type of planning, rather than a static and bureaucratic planning style, that might be used by a variety of local authorities in developing nations. 
This paper considers the land development process in Istanbul, Turkey. Istanbul is a very large, fast growing city, located in a vulnerable area. It is in an earthquake-prone region surrounded by salty water, and on two strips of land between Europe and Asia, and is thus in a sensitive position with regard to the provision of freshwater. Land development is structured by the challenge to protect those green areas that provide freshwater when rain falls.

In Istanbul, the public authorities (TOKI (Mass Housing Administration) and the municipalities) have become directly involved in the land development process in order to provide an answer to the two main problems that the metropolitan area faces: the low quality and quantity of the houses, and the high prices of serviced urban plots on the legal market. Resolution of these two basic problems is dependent on producing adequate dwellings in terms of both quality and number, and at reasonable price in the legal land market. This triggers the greenfield development of very fast growing cities like Istanbul and so the land development process becomes particularly important. This is the reason why this type of process affects production volume and price (Needham and Verhage, 1998).

The purpose of this paper is to discuss the development of greenfield sites in Istanbul, with emphasis on the institutional structure of the land development process of some recent largescale housing projects on a greenfield site. The paper also examines the roles of the main players. The analysis may be relevant to discussions on the development of policies which enhance the effectiveness of the process for housing within formal land markets in developing countries.

This paper is organized as follows: the theoretical framework is examined in the following section. The third section examines the role of public planning decisions and actions on the land development and its problems. The fourth section analyzes the development of publicprivate sector capacities in land development. The fifth section gives an institutional analysis of four different large-scale housing projects on greenfield land in Istanbul, the main players and their roles in these processes. The sixth section is a general evaluation of the case studies. Conclusions are then drawn and policy recommendations are made. 


\section{The Land Development Process}

Producing serviced plots for housing is part of the land development process, defined by Healey (1992) as a transformation of the physical form, the property rights and the material and symbolic value of land and buildings resulting from the effort of agents who both acquire and use their sources of power, namely, material resources, the making and enforcement of rules, and communicative powers, such as ideas and values.

This production process has several steps, and occurs within a certain structure and agency with two-way influences (see also Ball 1998; 2003). The steps in the production processes can be conceptualized as transactions, that is, exchanges between parties involving the promise of action or value by one party in exchange for money, goods, services or other valued resources or the promise of reciprocal action of economic or other value (Alexander, 2001a, p.775).

Although land development processes may change based on the specific, often national, contexts, the initial and final stages in the processing of greenfield areas are similar (Van Dijk et al., 2007, p.28). At the beginning, planning decisions and land usage functions are not defined for the land, and development rights are not yet assessed. Mostly, the land is used as open spaces or for agricultural purposes. At the final stage, housing areas with service and infrastructure areas (on-site and off-site) are produced. Intermediate stages may show a change depending on the instruments used and the roles of the players within the cultural context of the various counties, characteristics relating to supply and demand that are shaped within the economic context, and the basis on which the profits and costs are shared.

The land may be developed by a temporary landowner or by several different landowners (Needham and Verhage,1998; Van Dijk et al.,2007). Temporary ownership may be: public, e.g., the municipality purchases the land from the original owner, services it, and then disposes of the serviced plots (Needham, 1992; De Wolff, 2001; Groetelaers and Korthals Altes, 2004); a public-private joint venture company in which the risks of the project and the management of the land are shared by the local authority and private enterprise (Verhage,2002b; Leväinen and Korthals Altes, 2005); or a private land development company may purchase the land, service it, and transfer the public service areas to the municipality or public body, and then transfer serviced plots to another agent (Verhage, 2002a,b; Ball,2003). The development model by different landowners is based on existing owners that play a role in the process. The interaction between these owners and the local authorities may proceed in 
various ways, either by agreement or by the use of public powers, especially for acquiring, preparing and developing the land, to assure public interests.

The land development process takes place within the context of a specific spatial planning regime (Buitelaar, 2004) that influences the rights property owners have for developing land, and sets the rules, such as, accounting for the share of the common costs that the individual owners must bear, and the role the local authorities may play in changing the plans and zoning ordinances. In hierarchical planning systems higher-level statutory plan decisions are legally binding on local-level plans and all parties are obliged to obey these decisions. Local land-use plans that are prepared according to top-level plan decisions show the end-state. The development control is provided within the framework of the local plan. First, a plan is prepared. Serviced urban plots are then produced to implement that plan. Building permits are given to the serviced urban plots according to the development rights specified in the local plans. Flexibility in planning decisions is provided by means of plan updating or plan amendments, within the framework of top-down planning.

On the other hand, in the interactive policy network, the top-level plans guide the local landuse plans. The local planning process is a negotiated one. The making and implementation processes of the plan are combined. The different players mutually influence each other through the decision-making, and the realization of an urban development (Verhage, 2002b,p.7). A planning permit is an important tool in the implementation of a plan (Verhage,2000a).

Alexander (2001a, 2001b; compare Healey, 1992) has developed a generic model of the land development process, which includes the following stages: (1) land purchase and assembly; (2) financing; (3) land preparation and development; (4) land disposition; (5) construction; and (6) property transfer. According to Alexander (2001a; 2001b), this description of the land development process is a generic model, at a level of abstraction that fits any society which can be characterized as a market economy (Table 1). But this also means that it needs to be modified to reflect the specifics of a particular context. These include: the particular forms of governance and actual institutional framework of current land development and the property market which, of course, varies widely from place to place (Alexander 2001a, p.758).

$<<$ Table 1 >> 
Land acquisition or land assembly is seen as a sequence of transactions to buy land in an imperfect land market (Adams et al., 2001). Land assembly involves changes in land ownership through the acquisition of the necessary parcels of land to cater for property development and infrastructure provision (Louw, 2006). Purchasing is usually used for land assembly, though the local authorities may use instruments such as: compulsory purchase, pre-emption rights and land readjustment. The latter instrument allows the original property owners to become entitled to property rights on the serviced plots ( Turk, 2008; Turk, 2007; Muñoz Gielen and Korthals Altes, 2007).

The land preparation and development may be risky (Ball, 2003) as the land has to pass through regulatory procedures and the site has to undergo any necessary works required to enable individual building plots to be prepared, which may be expensive. A serviced urban plot for housing is a piece of land that is for residential usage according to the formal plan within an urban area. On-site and off-site service areas are provided within that area. On-site services include: roads, drainage, gas, electricity, open areas, parks, etc., while off-site services include arterial roads, sewerage plants, etc. The most important point at this stage is how the on-site and off-site areas (service and infrastructure areas) will be procured and who will carry out the development (construction work). Provision of on-site and off-site areas and meeting their costs differs according to the legal structures and land development models in the various countries.

Financing involves a separate transaction that brings other parties (which may be different in different countries) into the process. Private financial institutions (banks, insurance corporations, etc.), housing associations, labor unions and financial institutions, and governments may play a role (Alexander, 2001a) in this process.

The land disposition stage involves the sale or lease of a developed site to its final owners or users who undertake the construction of site improvements, buildings, plants, facilities and on-site infrastructure. When the buyer, developer and final user of an originally open or raw site are identical, this stage is absent (Alexander, 2001a).

Construction is one of the most complex stages in the land development process. This stage needs to use professional and contractor services. All building construction projects have 
some elements in common: design, financial and legal considerations. The parties traditionally supplying a construction project are design professionals who provide specialist advice concerning structural, electrical, mechanical and landscape details. The project management team manages the detail of the project and liaises between the client and the construction team. Cost consultants prepare the bills of quantities and cost plans. The main contractor manages the work on site and subcontractors supply specialist skills. Suppliers provide building materials and related components. A contractor usually undertakes to organize, move and assemble the various inputs, prepare the site before work commences, and manages the process thereafter. Various subcontractors contribute as the specific jobs require.

Property transfer is the final stage of the land development process. At this stage, the buildings have been built on serviced land. Transfer of the ownership of the improved real estate is handled by sale or lease.

If the local authorities opt to take a more direct involvement in the process, they need to acquire certain capacities (Korthals Altes, 2002; 2007). These can relate to accessing the necessary knowledge and skills, such as: about contracting with development companies, or the accounting for development projects, to engage in the transactions outlined above (Sagalyn, 2007), but it can also relate to obtaining finance. Local authorities in France and the Netherlands have, for example, access to cheap loans through AAA-rated banks (Kortals Altes, 2002). Local authorities in many American states are legally bound by stringent credit limits, and so have reacted by developing a practice of financing through property tax abatements (Sagalyn, 2007). As land development involves interaction between public and private agents, the changing roles of the public agencies, also involves capacity building of private agents (Ball, 2003). This paper will therefore analyze the capacity building of different agencies in relation to the supply of building plots for greenfield housing in Istanbul.

\section{The Formal Planning System in Turkey and the Problems in Housing Delivery}

A hierarchical, statutory planning system is responsible for land-use planning and development control in Turkey. The 1985 Reconstruction Law defined regional plans and local physical plans. According to this law, regional plans must identify the socio-economic development trends, development potentials and sectoral targets of the settlements. As of 2008, these plans have not yet been produced (Ersoy, 2000; Mengi and Keleş, 2003; Turk and Turk, 2006). 
Top-level land-use plans, based on the building code and regulations, must compensate for this deficiency. These plans each cover one or more provinces which have administrative, spatial and functional integrity. They aim to secure a balance between protection and use, between urban and agrarian structures, between development and leaving sites in their natural state, and cultural values, when determining land-use decisions. Next to the top-level plan, there is also the area master plan prepared for metropolitan areas. This plan includes basic land-use decisions in the metropolitan area and investment decisions at metropolitan scale.

The top-level land-use plan and metropolitan area master plan decisions are legally binding on local-level plans, and all parties are obliged to obey these decisions. For example, a mass housing project cannot be developed in an area which has been allocated an agricultural function in a top-level land-use plan, and that plan cannot be amended. Top-level land-use plan decisions or metropolitan area master plan decisions can only be changed under obligatory conditions and with "public interest" reasons, a concept that is stringently interpreted by the High Court (Geray,1997, p. 237). Moreover, there should be a balance between public interest and private ownership rights in plan amendments. The process for making any change is long and very difficult.

Within the group of local physical plans there is also a hierarchy between a higher local landuse plan and a detailed local plan that must conform to it. The local land-use plan shows the general land classes, land-use zones, population density of these zones, development direction and size of the settlement areas and their principles and resolutions relating to transportation. The detailed local physical plan shows building blocks, their density and structural arrangement (front, back and side yard distances), the height of the buildings, and roads (pedestrian and vehicle section). In metropolitan areas there are two levels of local authorities (Toprak, 2006), i.e., the metropolitan municipality that approves the local land-use plan, and on a lower level district municipalities and first-stage municipalities that approve detailed local plans.

In their turn, the local physical plans are hierarchical to decisions in the land development process, such as, the production of serviced parcels and the issuing of construction permits. 
As Crozier (1964) has already analyzed, it is difficult to accommodate change in hierarchical organizations that use conformance as a steering method between levels, this also applies to planning systems. The ability to accommodate change 'on a piecemeal basis' (Crozier, p. 196) may complicate the realization of legal development potential in a fast growing city like Istanbul.

To accommodate the development of mass housing projects on a greenfield area in a metropolitan area, a local physical plan decision for this development must be taken and submitted to the metropolitan municipal council for approval. A new plan has to be prepared if there is no local physical plan for the area which is to be developed. This can be in the form of an addendum or partial plan which, however, must conform to the top-level plan or the metropolitan area master zoning plan. In this case, it is necessary to prepare a plan proposal for a new local land-use plan (addendum or partial plan). When this proposal has been approved by the metropolitan municipal council, it is necessary to prepare the detailed local plan proposal, which may be prepared by private enterprise (landowners, developers, cooperatives, etc.) or public agencies (related municipality, public units). The prepared proposal is then submitted for the district municipal council's approval.

If a local physical plan exists, the process will be different for the project development area. Usually, local physical plans in new development areas are designed on the basis of an ownership structure (generally scattered ownership). It is assumed that the area will be developed by its owners. Development rights are relatively less dense in city center areas. This is not suitable for large-scale housing developments. Plan amendment or plan updating is necessary to fit the present local land-use plans to large-scale housing development. The plan amendment involves changing plan decisions at the parcel scale. And plan update means more extensive changes over a large part of the city or an overall plan. In Turkey plan amendments are based on the same basic principles. These principles are that: the changes must be based on rational reasons, must be in the public interest and must not oppose the integrity of the plan and its main decisions (Altın and Turk, 2005). A plan amendment must be made in accordance with the form defined in the Reconstruction Law. Plan amendments and updates must be submitted for approval by the council. The procedures for adopting plan amendments and updating the acceptance of offers are same as those for developing new plans.

In 1985 the authority to approve local physical plans was assigned to local administrations (municipalities) from the central administrations. With this authority, municipalities started 
plan changes at the beginning of 1990. Especially in Istanbul, the level of plan amendments has been high. In Istanbul during the 1980s, 400 changes were made, during the 1990s there were 450 changes, and since 2000 there have been 850 changes, while in the last 3.5 years there have been 3800 changes (CNN Turk, 21.07.2008). In most cases, these changes involved the increase of construction rights such as from service area function (parks, carparks and playgrounds etc.) in plan decisions to residence or trade function or increases in the floor area coefficient (Altın and Turk, 2005). The basic problem with a local detailed plan amendment is that most of these changes have no reasonable or suitable reasons according to law. As a result, most of these plan amendments can be nullified by the administrative courts. From this point of view, the demand for increasing construction rights for large-scale residences by private sector investors (landowners, developers, cooperatives, etc.) or the public sector mainly opposes the term public interest.

As indicated in the introduction, the Turkish planning system cannot prevent urban areas facing two problems: the deficiencies of the housing stock and the high prices for formal serviced plots.

The Turkish State Planning Organization (SPO) indicated that there was a need for growth in the housing stock (then 7,868,400 units in urban areas), but that only 6,221,915 permits for the construction of dwellings were issued in the period 1990-2005. The number of dwelling occupancy units was much lower $(3,632,123$ units), because many construction permits were given for illegal buildings under amnesty laws, and these were of insufficient quality to obtain occupancy permits (Housing Special Expertise Report, 2002). The quality of the present housing stock is not only a problem for former illegal dwellings. Especially in big cities the housing stock is aging, and the 1999 Marmara earthquake has sadly shown that a large part of the existing older housing is in a life-threatening condition. According to estimates by GYODER (Association of Turkish Real Estate Investment Companies), Turkey needs $650,000-700,000$ new units in order to meet the housing needs created by population growth, urbanization, replacement requirements and urban regeneration (Figure 1) (GYODER, 2006). The deficiencies of the dwellings not only relate to their quality, but are also related to the quality of the built environment that the houses are located in. In other words, the on-site and off-site areas are also inadequate. 
Prices of serviced urban plots with legal building status are high; the share of serviced urban plot prices in housing production with the official construction permits reaches $50 \%$ in the legal market (Alkan, 1999). This is different from the illegal land market, where much lower prices apply. It appears that the illegal land supply is much more elastic to demand than the supply of legal building land, which may be attributed to the hierarchical planning system in Turkey. Another feature is that the property rights in the illegal market are different (Healey, 1992). Property rights are mostly unclear in the illegal market and there are important risks with respect to future use. In practice, however, the illegal land market is an important, and more affordable, option for low- and middle-income families. A similar situation is also observed for other countries with a dual land market, such as in India where the share of the serviced parcel production in dwelling production is approximately 40-50\% (Karnad, 2008). Higher share of serviced urban plot prices in housing production are mostly prevalent in metropolitan cities of developed countries (Glaeser et al., 2005a,b). In more remote areas, however, this ratio may not exceed 10\% (EGEKOOP,1995).

The overall scene for Turkey also applies to Istanbul. Only $48 \%$ of the buildings have construction permits, and only 19\%, of the dwellings have occupancy permits. Many dwellings are built and used without construction permits (GYODER, 2006). The location is vulnerable to earthquakes, and many dwellings may collapse if the city is hit by one. Additionally, the costs of serviced urban plots in Istanbul are very high. The price of new residences, on average $700 € / \mathrm{m}^{2}$ in 2002 , increased to $1,900 € / \mathrm{m}^{2}$ in 2008 . The imbalance in the distribution of income in Turkey also leads to a wide variety in the price of residences. The top-end residences in Istanbul cost 5,000-7,000 €/m² (Yetkin, 2005). Most of the structures in the housing stock are directed towards middle- and upper-income groups. The higher returns from residential property have drawn an increasing interest from both domestic and foreign investors. Large international real estate firms have entered the market to produce residential property. Taking into account domestic investors and foreign investors' demands for eligible land, the pressure on urban land available for development is increasing.

Resolution of these two basic problems is closely related to the greenfield development of very fast growing cities like Istanbul and the subsequent land development process as well as the public-private capacity for land development. 


\section{The Development of Public / private Sector Capacities Land Development}

Small producers (one-man firms) or yap satcl dominated housing production up to the 1970s. These small constructors started by entering into an agreement with the landowners, offering $30-50 \%$ of the apartment units intended for a single plot to the owner in return for the land. Such an agreement made it possible for the yap satcı to commence work with a minimum capital outlay, just enough to build the basement and the first-floor apartments. In order to continue building the producer generally sold the first few flats once they have been completed (Oncü, 1988; Baharoglu, 1996 ). Thus, half of the residences built in the period from the 1950s to the mid-1980s were produced by this system (Sayar and Süer, 2006). Formal sources considered this "single plot-single building" approach as the basis of the land development process for housing. This approach still shapes the urban areas of the majority of medium and small cities in Turkey (Turk, 2004; Akdeniz, 2001). However, the transformation from small-scale (single plot-single building) into large-scale dwelling production (single plot-multiple buildings and units) which began in the 1980s, increased in the 1990s and the land development process in this transformation has not been sufficiently examined. The process for producing large-scale dwelling projects (mass housing areas), that has been introduced following the Mass Housing Law (1984) and Reconstruction Law No. 3194 (1985, still in effect), is different and more complex and with many more players in comparison with the traditional process. This difference was not sufficiently considered in these legal sources.

After 1980, the supply of housing based on small production (yap-sat style) ceased to be the prevailing supply form and was superseded by "mass housing cooperatives" that required larger and better-arranged urban areas to develop. Expansion by adding buildings to the city one by one, has changed to expanding by the addition of large blocks to the city, especially in large cities (Türel, 1989). Since the beginning of the 1990s, middle-upper and upper-income groups have started to settle in self-sufficient gated communities. This process has developed in three ways: villas with a garden outside the city, and mass housing blocks either in the city or mostly, in suburban areas. Most private developers focus on these housing projects. They prefer the suburban areas to develop these housing projects which offer their residents a high quality of life with social and environmental amenities included within the complex (Genis, 2007). Istanbul has become the focus for such investments. As mentioned before, in these types of projects, financing is procured by "pre-sale", and the company brand becomes 
important. Large developers, caring for their brand in the market, instead of small developers, have begun to play a role in the market.

Traditionally, the Turkish public sector has regulated the housing sector rather than investing directly in it, and did not play an active role in the provision of serviced urban plots for housing supply until the 1980s. Drastic changes in the political and economic situation of the country provoked a change (Türel, 1989; Baharoglu, 1996). TOKI was established apart from the General Administration in 1984, and a Mass Housing Fund provided it with resources for housing development. These resources diminished from 1993 onwards, and finally stopped in 2001. TOKI became dependent on the allocations transferred from the budget (www.toki.gov.tr). However, with the legal regulations in effect since 2000, TOKI's authority has widened and so its resources have increased. With an amendment (Law No. 4966; August 6 , 2003) TOKI became authorized to make a profit from projects and developments in order to provide resources for its activities. All the duties of the Land Office were delivered to TOKI by Law No. 5273 on December 15, 2004, and TOKI became authorized to hold land stocks, and it also received the right to expropriate and pre-empt the land belonging to private owners for housing, education, industry, health and tourism investments and public institutions. TOKI also became, with another amendment, authorized to make local physical plans for the areas where the property belonged to TOKI in case the land was zoned as a housing development or a mass housing area. The law was also changed so that the relevant Minister and Minister of Finance with the approval of the Prime Minister could authorize TOKI to use publicly owned land (Treasury land) without charge to develop projects.

With all these changes, both regulatory and as the owner of the land, TOKI has become an important player in the housing market by providing for around 5-10\% of the total housing need. Although these projects aim to provide suitable housing for the low-to-mid income groups, in Istanbul TOKI mostly prefers to develop mass housing projects for middle-to-upper income groups in order to raise finance for their other social housing projects.

Although the possibility was provided for the municipalities to produce housing in terms of the legal source (Law No. 5656 that was supplementary to Law No. 1580) since 1950, the power had rarely been used by the municipalities, except those in some large cities (Keleş, 1990). However, at the beginning of the 1990s, the metropolitan municipalities formed their own companies to start housing developments. According to Turkish Trade Law, municipal 
companies are private legal persons. Because of their structures, they work in accordance with the market rules and they remain outside the public audit field. These companies are controlled by the Commerce and Trade Ministry. Execution of these duties by municipalities through these companies is a type of internal subcontracting. Their decision-making bodies consist of members of the municipal council and the decision process is controlled by the executive of the municipal administration. However, the company as a private legal person has the role of competing and participating in the bidding. Corporate foundations are present in all metropolitan municipalities. $70 \%$ of the central province municipalities have at least one company or they are a partner in a company. The municipalities are also able to start a corporation in order to supply housing (www.yerelnet.com). KIPTAS, which belongs to the Istanbul Metropolitan Municipality is a significant model for this. Since 1995, KIPTAS has produced 25,877 housing units in Istanbul, 20,322 of which are on the European side of Istanbul and 5,555 of which are on the Asian side (www.kiptas.com.tr).

The legal arrangements related to land-property development by local authorities lagged behind practice. The laws of 2004 and 2005 (Nos. 5216, 5393) and bylaw (No. 25951) gave municipalities the right to start a corporation for developing, buying land, making expropriations, building houses (market and social houses) on this land and developing projects with banks, selling and leasing these properties within their borders. Municipalities can make collective and mutual projects together with enterprises, TOKI and other relevant public bodies and enterprises for producing dwellings and workplaces.

As a result of all these legal regulations, local administrations (metropolitan municipalities, municipalities) especially in large-scale housing production, play both a regulatory and a direct investor role. The roles of the municipalities as regulator are: producing serviced parcels of land for dwellings (these are obligatory duties), planning and approval, the right to use the public intervention instruments (expropriation, purchasing, etc.). The roles of the local administrations as direct investors are: implementing housing projects directly through their own companies, entering into projects for profit and establishing various partnerships.

\section{Land Development Process for Housing on Greenfield Sites in Istanbul: Some Cases}

Four cases are now used to examine the institutional structure of the land development process for large-scale housing projects in the greenfield areas of Istanbul. Each case 
represents an example of land development: by municipality, central government unit (TOKI), a public-private partnership (TOKI and a private developer), and a private developer within temporary ownership (Figure 2). Another criterion used to determine the case studies is to have at least 1000 dwellings and be important projects for Istanbul in term of the recent production of large-scale housing. Data in this paper were collected from different sources. Data related to the planning matters and land development were provided by the municipalities and secondary sources. Information related to land acquisition has been provided by the Güven study (Güven, 2007). The websites of some of the participants and secondary data were also used as sources.

When the studies started in terms of local physical planning in the case areas, a metropolitan area master plan dated 1980 was valid in Istanbul. However, our case areas are beyond the boundaries of this plan. For this period, there were no top-level plans to guide local physical plans in the case areas. As a result, planning studies were carried out directly with local physical plans, which was helpful in accommodating this development within the legal system.

The first case study is the Başakşehir mass housing area ( $1^{\text {st }}$ stage) of 3,004 dwellings built on 47 hectares located in the Küçükçekmece Municipality (Figure 3), and realized by KIPTAS, a subsidiary of the Istanbul Metropolitan Municipality. The project started in 1995 and at present, construction of the $5^{\text {th }}$ stage of the Başakşehir mass housing area is underway. After land sales, the Istanbul Metropolitan Municipality started local physical plan studies. Since there was no local physical plan for the area, a new local land-use plan and detailed local physical plan were made and approved in 1992. Plan decisions were directly for the mass housing project and there were more flexible construction rights for residential areas. For instance, there were different floor area coefficients and there were no height limits on the buildings.

The second case study is the Halkalı mass housing area of 11,410 dwellings (for the first three stages) built on 895 hectares also located in the Küçükçekmece Municipality and realized by TOKI (Figure 4). The area was announced as a mass housing project area in 1979. Two Italian architecture offices prepared preliminary studies for the local land-use plan, application plan drafts, and site plans and preliminary drawings for the residences. A local land-use plan proposal was submitted to the Istanbul Metropolitan Municipality in 1987 and 
approved in 1988. A decision to extend the metro system to the area provoked an amendment of the local land-use plan, which was approved by the Metropolitan Municipality on 22.04.1994, and a detailed local plan was approved on 17.11.1992 by the Küçükçekmece Municipality (Haksal, 1995).

The third case study is the Avrupa Houses Project of 1,368 dwellings on approximately 10 hectares of land in the Küçükçekmece Municipality (Figure 5), built within the scope of TOKI source development applications, and completed in 2004. The local physical plans and other plans were approved on 22.04.1992 with a land-use plan amendment by the Metropolitan Municipality and a detailed local plan approved by the Küçükçekmece Municipality on 17.11.1992 (Haksal, 1995). The project site was determined to be a "hospital area" in the plan dated 1992. Act No. 5162 gave TOKI planning authorization on its own land. Using this authorization TOKI prepared a partial plan that included the change in land use from being a hospital to being partly residential. TOKI's plan was approved by the Istanbul Metropolitan Municipality Council on 19.10.2004.

The fourth case is at Soyak Yenişehir and consists of 2,905 dwellings on 32 hectares in the Umraniye Municipality (Figure 6) realized by the private sector (a developer), and completed in 2004. During the acquisition of the area, the conditions of the detailed local plan dated 01.03.1984 were valid. In this plan, development rights for the project area were very low (at maximum two-story residences). The developer had not sought any amendment to the plan to increase the development rights, but waited for the development of the neighborhood of the project area. Meanwhile, because of the development of the Ataşehir residential area near the project area and because it is close to the second highway bridge across the Bosphorus, the potential value of the area had increased. For this reason, an update of the plans became a necessity and the Municipality started update studies in 1994. Planning studies were completed in 1998 and approved on 13.02.1998. With this new plan, 54\% of the project parcel was assigned as a service and technical infrastructure area, $42 \%$ as a residential area $(\mathrm{KAKS}=$ $1.5)$ and $4 \%$ as a trading area (Guven, 2007).

There are important differences in planning decisions and applications between the four cases. In the first three cases, there were new local physical plans for the project areas. And during this planning period, a different and more flexible approach was followed. This flexibility can be seen in the development rights and plan amendments during the process. Another point 
affecting the planning decisions and applications is the effect of the special purpose planning. As seen in the third case, TOKI has the authority to intervene directly in the planning process. In the fourth case, the municipality changed the plan due to the developments near the project area.

\subsection{Land Assembly}

Fundamentally, land assembly in the Turkish land development process can be realized in two different ways. First, the state may intervene by using public powers of land acquisition, like expropriation or land readjustment, without the consent of the landowners. Second, a purchase may be made within the framework of private law principles and market mechanisms.

Compulsory purchase by the state is allowed if the public interest so requires. The state may use this instrument to provide service land for mass housing project areas that have been determined by the authorities (Mass Housing Law No. 2985, Law No. 5273), to develop planned residential areas in slum prevention regions (Slum Law No. 775), to implement local physical plans (Reconstruction Law No. 3194 and its accompanying clauses; Municipality Law No. 5393) or to produce serviced land, housing and a mass housing area in order to properly provide urbanization and meet the housing needs of settlements (Metropolitan Municipality Law No. 5216, Municipality Law No. 5393; By-law No. 25951). In order to begin the process, the expropriation decision must first be formally approved.

Land readjustment is defined in the Reconstruction Law, and is applied to manage the readjustment and development of built or unbuilt areas, to produce serviced urban lands at forms and sizes which comply with the local physical plans, and to provide land for on-site and off-site service areas. The power to use this instrument to implement local physical plans is regardless of the landowners' demands (Turk, 2004; Turk, 2005).

The method of acquisition in the case studies differs. In the first case area (Başakşehir Mass Housing Project), cadastral studies had been completed in the 1950s. Most of the parcels in this area were registered in the name of the Government Treasury and the remainder was owned by individuals. The Metropolitan Municipality started land assembly studies for the project area in the 1990s. Acquisition of the land was performed by voluntary purchasing by the Istanbul Metropolitan Municipality. Afterwards, production of serviced urban parcels and the land readjustment method were applied to provide service and infrastructure areas. The 
region which includes the second case study (Halkalı Mass Housing Project) was announced as a mass housing project area in 1979. Expropriation studies were started. As a result of the studies, most of the land was transferred to the Land Office (a legal predecessor of TOKI). The remaining real estate belonged to the Treasury and private persons. A more detailed inspection was carried out for part of this region (Guven, 2007, p.86,87). Land readjustment was applied in the area in 1992 and the Mass Housing Administration, the Treasury and the Küçükçekmece Municipality participated as partners to these serviced parcels with specific shares as a result of this application. In the period 1992-1995 TOKI then bought out the other shareholders' share. In the third case study (Avrupa Houses), the land acquisition process was similar to that used in the second case. In the fourth case the land was assembled by the developer as a speculative investment, that is, the investor waited for the land to gain value before development took place (Güven, 2007).

When all four cases are examined, it can be seen that public power was used mainly for land acquisition in public initiative examples. In the first three cases, the land readjustment method was utilized for land acquisition as well as for purchasing (at market prices) and expropriation. In other words, a mix of public and private intervention instruments was used. In the fourth case, the land assembly was totally within the market mechanism.

The Treasury has the right to make direct sales to municipalities by an arranged protocol for sale to TOKI for use for mass housing. The first three studies involved this type of transaction. TOKI has since been authorized to take over the lands owned by the Treasury without charge with the agreement of the relevant Minister, and with the approval of the Prime Minister (www.toki.gov.tr).

\subsection{Land Disposition}

In the first case land disposition was realized just after the land acquisition. The Istanbul Metropolitan Municipality transferred the project site to KIPTAS by procurement. In the second case, there was no land disposition stage because the project was directly implemented by TOKI. In the third case, after the land acquisition stage the developer was chosen by the "open bidding method" within the "Revenue Sharing in Return for Land Sale" framework. Subsequent stages were realized by a developer, but TOKI stayed in the process as a partner. In the fourth case the entire project was realized by the one developer. There was no land disposition (Table $2 \mathrm{a}, \mathrm{b}$ ). 


\subsection{Financing}

Financing the land development process of mass housing projects in Turkey is done differently in public enterprise (TOKI, municipality) and private enterprise projects (developer, cooperatives, and individuals). However, the state's role is important for financing. This role is mostly to provide long-term loans that can be procured in two different ways. First, loans can be procured for both the technical services stage and the construction stage. The second way is for TOKI to procure loans for the building constructors (cooperatives, natural and legal persons and municipalities in order to sell) for housing and infrastructure construction. Utilizing these loans is dependent on particular rules, and the loans have to be repaid within 5-10 years. Along with this, loan support by the state has decreased significantly in recent years. It is certain that the most important reason for this is that the "Mass Housing Fund" (which was previously outside the general budget and first included in the general budget in 1993) was totally revoked by Law No. 4684, dated 20.06.2001. When this fund had been revoked, TOKI's resources dropped significantly and it became dependent on allocations transferred from the budget. TOKI then developed a new model in order to evaluate the lands which it held to provide resources: the "revenue sharing in return for land sale" scheme (www.toki.gov.tr). With this model, the basic principle is to gain profit by giving out the lands which are intended for sale by contract with a value above the market price. Bids are made by the open bidding method. Market conditions and the proposals made by an applicant determine the price of the work in these bids. The contractor giving the highest share to the administration is preferred primarily in construction works according to the revenue sharing in return for land scheme. Percentage-based sharing which implies the share ratio of the plus an income differential that may arise from the sales in later stages is also taken into consideration as part of the proposal. Contractors finance the projects planned to be developed and the risks relating to all kinds of transactions and construction costs in all kinds of procurement of infrastructure, service areas, construction permit and title deed stages. All taxes are met by the sale and marketing costs and the costs of producing the buildings. However, there is a court case against "the revenue sharing in return for land sale" scheme by-law related to TOKI's practice in the Supreme Court. The Court decided on a stay of execution until the case is resolved. The main reason given for the judgment is that the model does not comply with the legal bidding process (13 ${ }^{\text {th }}$ High Court, 26.10.2007, E. 2007/ $6240)$. 
"Pre-selling" is an important resource for private entrepreneurs (developers, small producers (yap satcl), etc.) wishing to finance mass housing projects in Turkey. Housing developers usually rely on the pre-sale method to finance their projects. Under this method, developers pre-sell the housing units at the beginning of the project and use the income to finance the construction. This diminishes the need for external debt as well as the equity contribution to

projects and frees the developer's existing capital for the acquisition of more land. If the developer already has the land, the level of profit can be much higher. Since homebuyers take on the developer's risk under this method, the developer's credibility and brand name become very important.

In the first case, while the land acquisition and off-site area development were covered by public finance (municipality budget), the on-site area development and construction stages were covered by KIPTAS. In the second case, the land acquisition, land preparation (both offsite and on-site area development) and construction stages were covered by TOKI. In the third case, land acquisition and off-site area development were covered by TOKI and land preparation and construction stages were covered by the developer. Here, private developers used the "pre-selling" method to raise finance. In the fourth case, the land acquisition, land preparation (on-site development) and construction stages were also financed directly by the developer (using “pre-selling”) (Table 2 a,b).

\subsection{Land Preparation and Development}

Acquisition of on-site and off-site (service and infrastructure areas) and afterwards development (construction works) of service and infrastructure areas in land development in Turkey have been separate processes. Three basic methods are used for the acquisition of service and infrastructure areas.

The first is the land readjustment (LR) method. In the LR process, the percentage contribution is calculated within the project area. The percentage is found by dividing the total area allocated for public use into the total areas of plots falling into readjustment. This percentage contribution is applied to each plot, and used to provide public areas such as roads, squares, parks, carparks and playgrounds in the LR areas. The contribution was increased from $35 \%$ to $40 \%$ by the law dated December 3, 2003 (No. 5006). The areas for elementary and secondary schools were included in the public use areas as a result of this modification. If the contribution percentage within the project area is larger than $40 \%$, the difference must be 
expropriated by the municipality in order to reduce the contribution percentage to $40 \%$. The new urban plots thus developed are distributed to the landowners according to the size of their land at their rate of involvement going into the readjustment. The fundamental principle behind the distribution is the allocation of urban plots to landowners from their original locations and in the form of independent ownership, as far as is possible (Turk, 2007; Turk and Turk, 2006).

The second is the voluntary method: the adaptation of cadastral parcels into detailed local plans without any LR. Here, the aim is to transform a cadastral plot into an urban plot by means of subdivision, consolidation and contribution for public use areas. This practice is only possible with the landowner's consent . As part of the voluntary method, those areas left for public services such as: roads, parks, parking, playgrounds, green areas, mosques or a police department and schools in the plan of the cadastral parcel are contributed for public use in compliance with the stated purposes. As for the parts corresponding to those areas such as hospitals, municipality service areas and other public facilities, they form the related parts separately while the remaining part is set as a proper urban plot in compliance with the detailed local plan and regulations (Turk, 2005). In case some parts that are separated are not appropriate for building construction according to detailed local plans and regulations or if the whole of the cadastral parcel is reserved for public services or public facility areas, this cadastral parcel or land should wait for its readjustment or it will be expropriated. According to the type used in practice, the voluntary method represents significant benefits for both landowners and municipalities in providing serviced land. It reduces the municipal costs in comparison to other methods and can be quickly implemented. The municipalities do not pay any value for on-site service areas. As the process is carried out in accordance with the demands of the people, the rate of litigation is very low. However, the voluntary method has certain disadvantages. The percentage contribution of each plot to the lands allocated for general services varies, this causes loss of income among the landowners and leads to injustice in the overall plan (Turk, 2004).

The third is the expropriation method which is used in two different ways in Turkey. First, it can be used directly to provide serviced urban land to develop mass housing projects and planned residential areas in slum prevention regions. These projects are generally located in newly developing urban areas or are outside municipal boundaries. The second version is used in the context of the LR process when it is needed to implement the local physical plans. The expropriation method is used in two ways within the LR process. The first one is the 
expropriation by the municipality of the difference in order to reduce the contribution to $40 \%$ if it is above $40 \%$ within the LR process. The second is the use of the expropriation method for the supply of public facilities such as hospitals, nurseries, official facilities, etc. (known as off-site service areas). The plots which are allocated for public services such as hospitals, nurseries, official facilities, etc. in the LR area within the LR process are settled by giving shares in proportion to the areas of all the original plots that fall into readjustment. These areas are acquired through the expropriation method by the relevant institutions (Turk, 2007).

For the acquisition of service and infrastructure areas, the results from Turk's (2004) survey show that $85 \%$ of the municipalities studied use the voluntary method as a means of producing urban plots. The results of such processes are entered in the official Registry of Title once the municipality has given its approval, and the owners are then granted building permits. Thus, most municipalities $(61.3 \%)$ use the voluntary method as their first choice.

The development (construction process) of service and technical areas like roads, squares, parks, carparks and playgrounds which are acquired by using land readjustment or the voluntary method are traditionally the responsibility of the municipalities. Municipalities meet the costs of these tasks, especially for roads, sewerage system and water facilities by contributions taken from landowners within the framework of Municipal Incomes Law No. 2464 as well as meeting the allocations that they take from the general budget. According to Article 23 of Reconstruction Law No. 3194, two conditions must first be satisfied in order to grant construction permits in newly developing urban areas. The first condition is that the serviced urban parcel must be produced. The second is that the roads, sewerage and drinking water networks must be constructed depending on the scheme and the conditions of the location. However, an exception is introduced in the law for the second condition by which a construction permit can be granted if the landowner accepts paying $25 \%$ of the technical infrastructure cost that falls on that share in cash, and then paying the remaining cost within six months. On the other hand, development of other public areas such as hospitals, municipality service areas and administrative service areas that are acquired by expropriation under the scope of land readjustment is provided by the authorized official body and this body's budget.

The land preparation stages of the examples demonstrate differences. In the first case study, the land acquisition for services and infrastructure used the LR method. While the development of off-site areas was realized by sub-contractors selected by the Istanbul 
Metropolitan Municipality, the development of on-site areas was realized by sub-contractors that had been chosen by KIPTAS. In the second case, the land acquisition was also provided by the LR method. The development of off-site and on-site areas was realized by subcontractors that had been chosen by the TOKI procurement process. In the third case, land acquisition of service and infrastructure was also provided by using the LR method. Off-site areas were realized by sub-contractors that had been chosen by TOKI. On-site areas were developed within the framework of a contract revenue sharing scheme in return for the sale of the land to the developers. In the fourth case the service and infrastructure areas were acquired by the voluntary method. Initially, the land developer did not want to cede $54 \%$ of the parcels determined for the services and infrastructure in the detailed local plan. If a land readjustment project that comprised the project site was implemented by the municipality, up to $35 \%$ of the developer's land would be taken as the contribution without any payment. The rest (19\%) would have been expropriated by the municipality in order to reduce the contribution to $35 \%$. A solution was negotiated between the municipality and the developer. The municipality added a plan note to their development plans and it was decided that the development right would be defined on $65 \%$ of the cadastral parcel. This meant that the right to development was given to the landowner in return for the remaining excess parcel. The developer then transferred 54\% of the land to the public without charge. After this acquisition, the development of service and technical infrastructure areas was ensured by the municipality, but on-site area development was provided by the developer (Table $2 \mathrm{a}, \mathrm{b}$ ).

\subsection{Construction}

In the first case study, the construction stage was realized by KIPTAS who awarded it to various subcontractors. In the second case, the construction stage of the project was awarded to various subcontractors. In the third case, the contract was assigned by the open bidding method. All works at the construction stage were fulfilled by the developer who worked with various subcontractors. In the fourth case, all works relating to the construction were fulfilled by the developer, who used various subcontractors.

\subsection{Property Transfer}

In the first case study, the property was transfered through sale. However, primary applications for the sales were accepted and the final users were then determined by the drawing of lots because of excess demand for the property units. Housing loans, under defined conditions, were made available to the purchasers.. In the second case, the property 
was sold by TOKI (housing loans were also made available). In the third area, the price, date and management for the sale of the housing units were determined by TOKI. In other words, the developer required TOKI's consent for all the transactions. However, on the basis of this agreement, the developer was responsible for sales and marketing. In the fourth case study, the sales were made after the permits had been received. The land registration documents were immediately delivered to the buyers, who had paid in advance to ensure their ownership. The loans had repayment terms of 10 years. The title deeds to the housing units will be delivered after the debt has been repaid in this type of sale (Güven, 2007) (Table 2 a,b).

\section{Discussion}

In these four cases, the original landowners were outside the land development process. In other words, the traditional model of land development by different landowners has changed. Along with this, the development of greenfield sites in large cities has started to transform from small-scale (single plot-single building) which came into sight in the 1980 s and increased in the 1990s to the large-scale (single plot-multiple buildings and units) production of dwellings. Istanbul is an important example of this transformation process, which can be clearly seen in the case studies. Land development processes in large-scale housing development are complex and involve many players.

In accordance with these four cases, when looking at planning decisions and action, it can be seen that a more flexible approach to development rights and plan amendments during the process was followed for the first three cases. Another important point affecting the planning decisions and applications is the effect of the authority of special purpose planning. Additionally, when looking at the land development process, it is seen that none of the acquisition methods was used alone. Both in terms of public and private law, there are methods that have to be used together. The situation faced in practice is that the acquisition method based on public law was used mostly at the beginning of the process. Once urban land that is suitable for development has been aquired, methods based on private law are usually used.

When our findings are evaluated in terms of the players, important changes are seen in their roles. The traditional role of the government is to promote and regulate the development 
process by using laws, levying taxes, administering regulations, giving subsidies, building and maintaining infrastructures and providing services (Han and Wang, 2003). In the traditional role, the public sector acts as the "provider" of a coordinated, stable framework for making investment decisions, as well as providing serviced land and development (Healey, 1997,p.11). The first three cases indicate that TOKI and the municipalities have invested in large-scale housing projects. At the same time, their regulatory roles have been empowered by various legal instruments. For example, at the beginning of two cases, neither TOKI nor municipalities had any direct expropriation authority to acquire land for large-scale housing projects. Additionally, at the beginning of the second case TOKI had no special planning authority. Besides these subsequent regulatory authorities, the other important change in their roles is that TOKI and the municipalities have entered into specific contractual partnerships with private sector developers and have built up joint-venture relationships in the land development process for large-scale housing projects. They have also entered into profitmaking projects.

\section{Conclusions}

In Turkey, both the central government unit (TOKI) and the local units (municipalities) started to take an active role in the production of serviced parcels of urban land and of housing in the $1990 \mathrm{~s}$, but in the first decade of the $21^{\text {st }}$ century their roles were considerably strengthened, so that, in cooperation with the private sector, they are now major players in the Turkish housing market.

TOKI and the municipalities can make decisions on investments related to the residences, location, preparation of plans relating to the project and income groups that the project is aimed at. Taking into account all the other players (small producers, developers, cooperatives, private entrepreneurs, etc.) in the housing market beginning in the 1980s, it is obvious that the public (both TOKI and the municipalities) now have an important advantage. TOKI and the municipalities are able to use direct public intervention instruments, apart from private law instruments, especially in the acquisition of land for mass housing, the production of serviced urban parcels, and housing production. In addition to these, TOKI and the municipalities have a voice about the development rights given to the area because they are the planning authorities. These advantages are essential for the development of large-scale housing projects. For example, one of the most important factors in the development of these projects is the availability of large, problem-free parcels of land. In Turkey, lands in cities and on the periphery mostly have a scattered ownership structure. That type of structure can be resolved 
with the use of public intervention instruments (expropriation, readjustment, pre-emption rights, etc.). Again, TOKI and the municipalities can purchase land from the Treasury in order to produce dwellings. Even so, with the legal regulations made, TOKI has been authorized to take over the lands owned by the Treasury without charge, with the consent of the relevant Minister, and with the approval of the Prime Minister. This situation resolves the problem of land acquisition, which is the most important element in large-scale housing development. In this situation, the latest changes provide significant privileges to the public in serviced land production and the housing development process. All these advantages are seen in the case studies.

Another important point in the cases studied is that the building development process is either realized directly by the private sector or within the principles of private law by public-private partnerships. It can be said that the public authority (TOKI or the municipalities) provides housing production with private sector understanding. In other words, profiting from the project is the main point. For example, TOKI's revenue sharing scheme in return for the land sale with the private developers is shaped wholly by the profit motive.

The main point is how the structure formed by these new changes will respond to two basic problems in Turkey and its biggest city, Istanbul, as stated at the beginning of this paper. It can be said that, with these changes, the production in the sense of number has been improved. However, two main problems remain. First, the housing supply is still insufficient for low-income groups. The residences produced in Istanbul by TOKI, the municipalities, developers, cooperatives, and small producers were intended for middle- and upper-income groups. But $52 \%$ of the 3,136,931 houses in Istanbul do not have construction permits. This majority has little chance to benefit from this new housing. A newly enacted mortgage law is far from ensuring this. Secondly, prices are still high. Indeed, the "revenue sharing in turn for the land sale" model applied by TOKI can encourage price rises. However, price rises can be prevented in a housing market in which the public is effective. The resolution of these two basic problems depends on the policies that the public authority (TOKI and the municipalities) will apply. First, TOKI and the municipalities must make decisions on investments related to residence, choice of project place, preparation of plans relating to the project and income group that the project aims for as a whole and coordinate with each other. This makes it easier to intervene on prices. The public authority must also make the supply of accomodation for low-income groups a priority in Istanbul. 


\section{REFERENCES}

Adams, D., Disberry, A., Hutchison, N., Munjoma, T., 2001. Ownership Constraints to Brownfield Redevelopment, Environmental and Planning A, Vol. 33, pp. 453-477.

Akdeniz, H., 2001. The Land Readjustment in the Implementation of Local Physical Plans (Imar Planlarinin Uygulanmasinda Arazi ve Arsa Düzenlemesi). Teknik Yayinevi, Ankara (in Turkish).

Alexander, E. R., 2001a. A Transaction- Cost Theory of Land Use Planning and Development Control, Town Planning Review,72, pp. 45-75.

Alexander, E. R., 2001b. Governance and Transaction Costs in Planning Systems: A Conceptual Framework for Institutional Analysis of Land-use Planning and Development Control- the case of Israel, Environment and Planning B: Planning and Design 2001, Vol. 28, pp. 755-776.

Alkan, A., 1999. Housing problems of low income groups after 1980 and housing cooperatives (Türkiye'de 1980'den Sonra Dar Gelirlilerin Konut Sorunu ve Konut Kooperatifleri), Ankara: TÜRKKENT Yayını.

Altın. Y., Turk, S. S., 2005, An analysis related to plan amendments in Istanbul metropolitan area. (İstanbul Metropoliten Alanında İmar Planı Değişiklikleri İle İlgili Bir Analiz) 8 Kasım Dünya Şehircilik Günü 29. Kolokyumu Planlamada Yeni Politika ve Stratejiler, Riskler ve Fırsatlar, 7-9 Nov., 2005, Taşkışla, Istanbul.

Baharoglu, D., 1996. Housing supply under different economic development strategies and the forms of state intervention: The experience of Turkey, Habitat International, 20 (1), 43-60.

Ball, M., 1998. Institutions in British property research: a review, Urban Studies, Vol. 35, pp. 1501-1517.

Ball, M., 2003. Markets and structure of the housebuilding industry: an international perspective, Urban Studies, 40, pp. 897-916. 
Buitelaar, E., 2004. A Transaction-cost Analysis of Land Development Process, Urban Studies, Vol. 41, No. 13, 2539- 2553.

CNN Turk, 21.07.2008.

Crozier, Michel, 1964. The Bureaucratic Phenomenon, Chicago: The University of Chigcago Press.

De Wolff, H., 2001. Development of land for new urban areas:in search of a new approach, in Transactions in International Land Management (Eds) R.W. Dixon-Gough, R. Mansberger, Ashgate, pp. 81-99.

EGE-KOOP, 1995. Cooperatives towards 2000. (2000’e Doğru Kent Kooperatifçiliği), Izmir.

Ersoy, M.., 2000. İmar planı uygulamalarında düzenleme işlemi .(Land readjustment process in the implementation of local physical planning), In: Ersoy, M. Keskinok, C. (Ed.) ., Mekan Planlama and Yargı Denetimi (Local Pysical Planning and Legal Control), Ankara, Yarg1 Yayınevi, pp. 72-98 (in Turkish).

Geray, C., 1997. Planning and organization for regional Development (Bölgesel Gelişme için Planlama ve Örgütlenme), AUSBFD, 52, 1-4.

Genis, S., 2007. Producing Elite Localities: The rise of gated communities in Istanbul, Urban Studies, Vol. 44, No.4, pp. 771-798.

Glaeser, E., Gyourko, J., Saks, R., Why have housing prices gone up?, American Economic Review 95 (2005), pp. 329-333.

Glaeser, E., Gyourko, J., Saks, R., 2005 a. Why is Manhattan so expensive? Regulation and the rise in the house prices, Journal of Law and Economics, 48, pp. 331-370.

Groetelaers, D. A., Korthals Altes, W. K., 2004. Policy instruments in the changing context of Dutch land development, in: M. Deakin, R. Dixon-Gough \& R. Mansberger (Eds.) Methodologies, Models, and Instruments for Rural and Urban Land Management, Aldershot, Ashgate, pp. 75-87. 
Güven, O., 2007. Land acquisitions for large scale housing projects: Istanbul Case. (Büyük Konut Projeleri İçin Arazi ve Arsa Edinim Metodları: İstanbul Örneği), Unpublished Msc Thesis, Institute of Science and Tecnology, ITU.

GYODER, 2006. Real Estate Sector and foresight for Istanbul. (Gayrimenkul Sektörü ve Istanbul İçin Öngörüler), Istanbul.

Haksal, I., 1995. Comparative examination new mass housing areas: Bahcesehir, Halkalı, Ataköy, (Toplu Konut Yolu İle Oluşan Yeni Yerleşim Alanlarının Karşılaştırmalı İncelemesi Bahçeşehir, Halkalı, Ataköy Örneği), Unpublished Msc Thesis, Institute of Science and Tecnology, ITU.

Han, S. S., Wang, Y., 2003. Institutional Structure of a Property Market in Inland China: Chongqing, Urban Studies, Vol. 40, pp. 91-112.

Healey, P., 1997. An institutionalist approach to spatial planning, in Making Strategic Plans: Innovation in Europe Eds. P. Healey, A. Khakee, A. Motte, B. Needham, UCL Press, London, pp. 21-38.

Healey, P., 1992. An institutional model of the development process, Journal of Property Research, 9, pp. 33-44.

Karnad, R. S., 2008. Chanelling financial flows for adequate and affordable housing, FIG Working Weeks, 14-19 June, Stockholm, Sweden.

Keles, R., 1990, Urbanization Policy (Kentleşme Politikas1), Ankara, İmge Pub., No. 13, 1990.

Korthals Altes, W. K., 2002. Local Government and the Decentralization of Urban Regeneration Policies in the Netherlands, Urban Studies, 39(8) 1439-1452.

Korthals Altes, W. K., 2007. The impact of abolishing social-housing grants on the compactcity policy of Dutch municipalities. Environment and Planning A 39 (6), pp. 1497-1512. 
Leväinen, K. I., Korthals Altes, W. K., 2005. Public Private Partnership in Land Development Contracts - A comparative study in Finland and in the Netherlands, Nordic Journal of Surveying and Real Estate Research, Vol. 2, 2005, pp. 137-148.

Louw, E., 2008. Land assembly for urban transformation: The case of Hertogenbosch in The Netherlands, Land Use Policy, Vol. 25, Issue 1, January, pp. 69-80.

Mengi, A., Keles, R., 2003. İmar Hukukuna Giriş (Introduction to Development Law), İmge Kitabevi, Ankara (in turkish).

Munoz Gielen, D., Korthals Altes, W. K., 2007. Lessons from Valencia: Separating infrastructure provision from land ownership, Town Planning Review, 78(1), pp. 61-79.

Needham, B., Verhage, R., 1998. The effects of land policy: quantity as well as quality is important, Urban Studies, 35 25-44.

Needham, B., 1992. A theory of land price when land is supplied publicly, Urban Studies, 29, 669-681.

Oncu, A., 1988. The politics of the urban land markets in Turkey: 1950-1980, International Journal of Urban and Regional Research, 12, 38-64.

Sagalyn, L. B., 2007. Public/Private Development, Journal of the American Planning Association, 73(1), 7-22.

Sayar, Y. and Süer, D., 2006. İzmir'de Alternatif Bir Konut Alanı Karşıyaka Emlak Bankası Uygulama, (An alternative housing area: Real Estate Bank applications in Karşıyaka), Ege Mimarlık Dergisi Sayı 57, Mimarlar Odası İzmir Şubesi, İzmir (in Turkish).

State Planning Organization, Sekizinci Beş Yıllık Kalkınma Planı, Konut Özel İhtisas Komisyonu Raporu, (8th Five Year Development Plan, Housing Special Expertise Report), Ankara, 2001 (in Turkish). 
State Planning Organization, 2005 Y11 Programı (Programme in 2005), Ankara (in turkish).

TOKI, 1990. Halkalı toplu konut yerleşmesi raporu , (Halkalı mass housing area report), T.C. Başbakanlık Toplu Konut İdaresi Başkanlığı Yayınları, (in turkish).

Toprak, Z., 2006. Yerel Yönetimler (Local Governments), Nobel Kitabevi, Ankara, ISBN. 9944-77-038-8, (in turkish) .

TUIK, 2005, Building Permit Statistics, Ankara.

Turel, A (1989) 1980 Sonrasında konut üretiminde gelişmeler (The developments in the housing production after 1980), ODTU Mimarlık Fakültesi Dergisi, 9(2), pp.137-154.

Turk, C., Turk, S. S., 2006. Hukuki ve Teknik Boyutları ile Arazi ve Arsa Düzenlemesi, (Land Readjustment with legal and technical dimensions), Beta Yayınları, Istanbul, ISBN 975-295-560-6, 2006, (in turkish)

Turk, S. S., 2004. The applicability of land acquisition methods for the provision of serviced residential land in the Turkish case, International Development Planning Review, 26 (2), 2004, 141-166.

Turk, S. S., 2005. Constraints Affecting the Efficiency in Use of Land Readjustment Method in Turkey,Cities, 22 (1) Feb. 29-42 (SSCI Index).

Turk, S .S., 2007. An Analysis on the Efficient Applicability of the Land Readjustment (LR) Method in Turkey", Habitat International, Vol. 31, Issue 1, March 2007, pp. 53-64.

Turk, S. S., 2008. An Examination for Efficient Applicability of the Land Readjustment Method at the International Context, Journal of Planning Literature, Vol. 22 No. 3 (February 2008), pp. 229-242.

Van Dijk, T., Munoz Gielen, D., Groetelaers, D. A., 2007. Expanding Cities: A grounded conceptual model that allows comparing systems of greenfield land development, Town Planning Review, Vol. 78 (3), pp. 279-310. 
Verhage, R., 2002a. Induced Cooperation in Housing Development: Comparing Housing Schemes in Four European Countries, European Planning Studies, Vol. 10, No. 3, pp. 305320.

Verhage, R., 2002b. Local Policy Housing Development European Experiments, Ashgate pub.

Yetkin F., 2005. (Real Estate ) Emlak G.Y.O. A.Ş. Elegans Magazine. No. 73 July-August 2005.

Zevenbergen, J., 2004. A Systems Approach to Land Registration and Cadastre, Nordic Journal of Surveying and Real Estate Research, 1, 11-24.

www.kiptas.gov.tr

www.toki.gov.tr

www.yerelnet.org 